University of Nebraska - Lincoln

DigitalCommons@University of Nebraska - Lincoln

Agronomy \& Horticulture -- Faculty Publications

Agronomy and Horticulture Department

$11-1962$

\title{
A Modified Procedure for Assay of Melilotic Acid in Sweetclover1
}

Walter R. Akeson

University of Nebraska-Lincoln

Francis A. Haskins

University of Nebraska-Lincoln, fhaskins@neb.rr.com

Herman J. Gorz

United States Department of Agriculture

Follow this and additional works at: https://digitalcommons.unl.edu/agronomyfacpub

Part of the Plant Sciences Commons

Akeson, Walter R.; Haskins, Francis A.; and Gorz, Herman J., "A Modified Procedure for Assay of Melilotic Acid in Sweetclover1" (1962). Agronomy \& Horticulture -- Faculty Publications. 244.

https://digitalcommons.unl.edu/agronomyfacpub/244

This Article is brought to you for free and open access by the Agronomy and Horticulture Department at DigitalCommons@University of Nebraska - Lincoln. It has been accepted for inclusion in Agronomy \& Horticulture -Faculty Publications by an authorized administrator of DigitalCommons@University of Nebraska - Lincoln. 


\title{
A Modified Procedure for Assay of Melilotic Acid in Sweetclover
}

\author{
Walter R. Akeson, F. A. Haskins, and H. J. Gorz
}

$\mathrm{K}^{\mathrm{o}}$

OSUGE and Conn $(5,6)$ observed that excised sweetclover shoots effect a rapid conversion of administered coumarin to melilotic acid (o-hydroxyhydrocinnamic acid). Although doubt has been expressed as to the existence of molecular coumarin in intact sweetclover tissues $(3,8)$, the closely related compounds, o-coumaric acid and coumarinic acid (the trans and cis isomers, respectively, of o-hydroxycinnamic acid) are clearly present in glucosidic form $(2,4)$ and these compounds may possibly serve as normal preiursors of melilotic acid. In previous studies on sweetclover (1) the glucosides of 0 -coumaric and coumarinic acids have been assayed together as bound coumarin, and the genetic control of bound coumarin level has been demonstrated. Because of the possible metabolic relationship between o-hydroxycinnamic and melilotic acids, genes influencing content of the former compound might reasonably be expected to affect level of the latter. Investigations of this and other problems concerning melilotic acid in sweetclover require an accurate assay method. Such a method is described in the present report.

The method described is based upon the procedure of Roberts and Link (7), but differs from this procedure in several way's, the most important of which are the following: (a) Hot water rather than organic solvents is used for extraction of the plant tissues. Both free melilotic acid and melilotyl glucoside are extracted by this means, and the enzymatic hydrolysis of the glucoside during extraction is minimized. (b) Heating the extract in acid, rather than incubating the macerated tissue in water before extraction, is used as a means of hydrolyzing melilotyl glucoside. This change is necessary because other work has shown that preparations of tissues representing certain genotypes of iweetclover are virtually devoid of $\beta$-glucosidase activity (9), and the enzymatic hydrolysis of melilotyl glucoside in the Roberts and Link procedure is apparently dependent upon this enzyme. (c) Paper chromatography of the hydrolyzed plant extracts is used to eliminate compounds which otherwise would interfere with the colorimetric assay.

\section{PLANT MATERIAL AND PROCEDURE}

Four lines of sweetclover (Melilotus alba Desr.) homozygous with respect to the $C u / c u$ and $B / b$ alleles were used in this study. The derivation of these lines was described earlier (3). Briefly, the characteristics of the lines with respect to glucosidically-bound o-hydroxycinnamic acid and the activity of $\beta$-glucosidase are as bollows: $C u C u B B$--high in o-hydroxycinnamic acid, high in -gluiosidase activity; $C u C u b b-$ high in o-hydroxycinnamic acid, lacking a $\beta$-glucosidase activity; cucuBB-low in o-hydroxycinnamic acid, high in $\beta$-glucosidase activity; and cucubb--low in o-hydroxycinlamic acid. lacking in $\beta$-glucosidase activity. Each genotype was represented by approximately 50 plants grown in flats of soil in the greenhouse.

\footnotetext{
${ }^{1}$ Cooperative investigations of the Crops Research Division, ARS, USDA, and the Nebraska Agricultural Experiment Station. Research was supported in part by the National Science Foundaion (Grant No. G 13182). Most of the data were taken from a hesis submitted by the senior author in partial fulfilment of the requirements for the M.S. degree. Published with the approval ff the Director as Paper No. 1233, Journal Series, Nebraska Agr Exp. Sta. Received May 14, 1962.

${ }^{2}$ Graduate Assistant in Agronomy and Professor of Agronomy, University of Nebraska, and Research Geneticist, Crops Research Division, ARS. IISDA, respectively.
}

The terminal 3- to 4-inch portions of several branches from each plant were removed and the cut ends of the stems were immediately immersed in water. These stems were then taken to the laboratory where the youngest fully-expanded leaf was harvested from each stem. The total sample consisted of approximately $2 \mathrm{~g}$. (fresh weight) of young leaves for each genotype. One side-leaflet of each leaf was used in a composite sample for dry-weight determination, and the other side-leaflet and the mid-leaflet were used in a composite sample for extraction and assay.

Melilotic acid and melilotyl glucoside were extracted by dropping the leaflets into boiling water $(15 \mathrm{ml} / \mathrm{g}$. fresh tissue) to inactivate $\beta$-glucosidase and autoclaving immediately at 15 psi for 15 minutes. The resulting extract was decanted from the leaflets and centrifuged approximately $5 \mathrm{~min}$. in a clinical centrifuge. The supernatant was used in subsequent steps of the procedure.

To $2 \mathrm{ml}$. of the supernatant $1 \mathrm{ml}$. of $3.0 \mathrm{~N} \mathrm{HCl}$ was added, and the solution was autoclaved for $30 \mathrm{~min}$. at $15 \mathrm{psi}$ to hydrolyze: melilotyl glucoside. The hydrolyzed solution was partialiy neutral. ized by the addition of 1 ml. of $2.5 \mathrm{~N} \mathrm{NaOH}$, centrifuged to eliminate a precipitate which had formed, and chromatographed.

Both hydrolyzed and nonhydrolyzed samples of extract werc chromatographed on $9 \times 11$ inch sheets of Whatman No. 1 filter paper. Aliquots chromatographed usually contained between 1.5 and $7.5 \gamma$ of melilotic acid, but these quantities do not represent the limits of the method. The aliquots were applied in a band along a line near the lower edge of the paper. In addition, a spot of the sample was made neas one end of this same line. This spot was overspotted with approximately $2 \gamma$ of authentic melilotic acid (obtained from the $\mathrm{K}$ and $\mathrm{K}$ Laboratories), to assist in later location of the melilotic acid band. Chromatograms were developed with an ascending solvent consisting of 3 volumes of $n$-propyl alcohol and 1 volume of $5 \%$ aqueous ammonia

After ascent of the solvent, air-dried chromatograms were examined under ultraviolet light, and the yellowish-green fluorescent a-coumaric acid band was marked. Becausc this band was slightly below and clearly separated from the melilotic acid band, its position helped to locate the melilotic acid band. The edge of the shect on which authentic melilotic acid had been chromatographed was sprayed with diazotized sulfanilic acid (10) and $5 \% \mathrm{Naly}_{2} \mathrm{CO}_{3}$ in order that the melilotic acid spot might be detected.

Using the $o$-coumaric acid band and the melilotic acid reference spot as guides, the melilotic acid band was marked and cut out Water was allowed to pass through this band in the direction of its longer dimension, in a descending chromatography system. In this system, melilotic acid moves at the solvent front. The eluate collected from the lower end of the paper section was diluted to $2 \mathrm{ml}$. A $0.5-\mathrm{ml}$. portion of diazotized p-nitroaniline (7) was added, followed by $0.5 \mathrm{ml}$. of $5 \% \mathrm{Na}_{4} \mathrm{CO}_{3}$. Color intensity was determined immediatcly with a Bausch and Lomb Spectronic 20 colorimeter set for a wavelength of $490 \mathrm{~m} \mu$.

Because the chromatograph paper contains some materials which react with the color teagents, care was taken to use chromatogram sections appproximately equal in size for elution. In addition, an eluate from a developed chromatogram to which no plant extract had been applied was used in preparing the colorimeter blank.

Melilotic acid equivalence values were read from a standard curve, and melilotic acid contents of the tissues were calculated on a dry-weight basis.

\section{RESULTS}

Adequacy of procedure-Efficiency of hydrolysis of melilotyl glucoside was tested by autoclaving portions of a plant extract representing the $\mathrm{CuCuBB}$ genotype in $\mathrm{NaOH}$ and $\mathrm{HCl}$ under various conditions. For $\mathrm{NaOH}$, concentrations of $0.8 \mathrm{~N}, 1.7 \mathrm{~N}$, and $3.3 \mathrm{~N}$ were used, and the solutions were autoclaved for $30 \mathrm{~min}$. For $\mathrm{HCl}$, a concentration of $1.0 \mathrm{~N}$ and autoclaving times of $7,15,30$, and $60 \mathrm{~min}$. were employed. Melilotic acid levels observed following the 30-min. $\mathrm{HCl}$ treatment were higher than those resulting from the $\mathrm{NaOH}$ treatments and the $\mathrm{HCl}$ treatments of shorter duration, and approximately equal to those obtained from the longer $\mathrm{HCl}$ treatment. Thus, the $30-\mathrm{min}$. autoclav- 


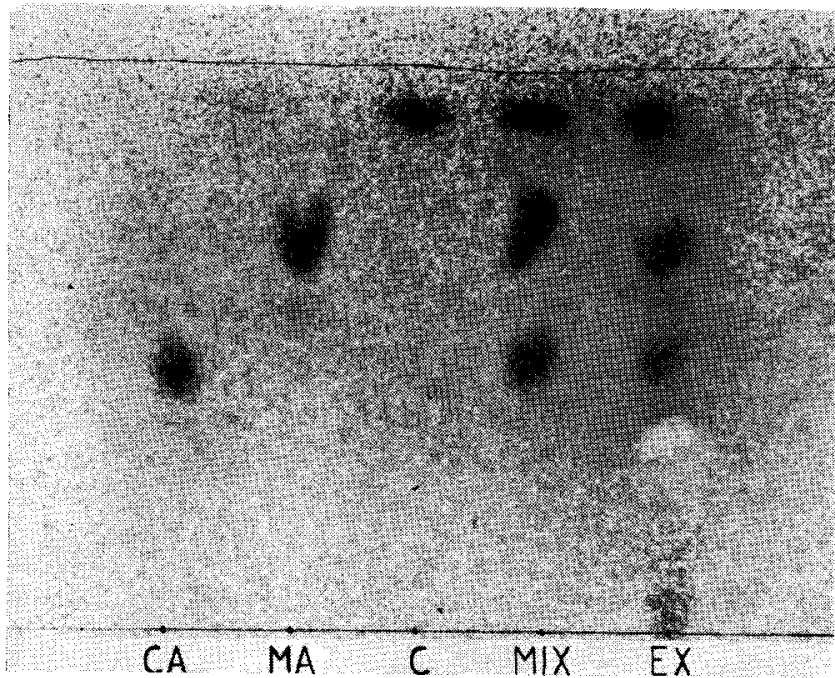

Figure 1-Chromatographic behavior of o-coumaric acid (CA) melilotic acid (MA), and coumarin (C); and separation of the 3 compounds in an artificial mixture (MIX), and in a hydrolyzed extract (EX). The solvent consisted of 3 volumes of $n$-propyl alcohol and 1 volume of $5 \% \mathrm{NH}_{4} \mathrm{OH}$.

ing in $1.0 \mathrm{~N} \mathrm{HCl}$ appeared to hydrolyze melilotyl glucoside adequately.

The effectiveness of the chromatographic system for separating melilotic acid from coumarin and o-coumaric acid (the two compounds in acid-hydrolyzed extracts of sweetclover leaves most likely to interfere with the melilotic acid assay) is illustrated in Figure 1. Recovery of melilotic acid chromatographed alone and in combination with coumarin and $o$-coumaric acid is shown in Table 1. Although chromatography with the $n$-propyl alcohol-ammonia solvent clearly separated melilotic acid from coumarin and $o$-coumaric acid, the possibility of interference by other substances was not excluded. On the basis of results obtained with two-dimensional chromatography, however, such interference did not seem to be appreciable. The $n$-propyl alcohol-ammonia solvent was used in the first dimension, and a benzene, propionic acid, water mixture (62.5:36:1.5, by volume) was used in the second dimension. This chromatographic procedure revealed the presence, in hydrolyzed extracts of leaves representing the $C u C u B B$ genotype, of several compounds which reacted with the color reagents. However, the n-propyl alcohol-ammonia solvent adequately separated melilotic acid from these contaminants.

Excellent recovery of melilotic acid, added to plant extract before hydrolysis, was achieved. Thus, in a series of four determinations involving addition of measured amounts of melilotic acid to plant extract, followed by hydrolysis of the mixtures and assay of the hydrolysates, eluates from chromatograms expected to contain $3.00 \gamma$ of added melilotic acid plus $4.49 y$ of melilotic acid from the extract were observed to contain $7.48 \pm 0.15 y$ of melilotic acid $(99.8 \%$ recovery)

Assay of melilotic acid in four genotypes of sueetcloner. -Free and total melilotic acid were assayed in leaf extracts from the four homozygous genotypes listed under Plant Material. The results presented in Table 2 indicate that levels of free melilotic acid were low and not greatly different for the four genotypes .Total melilotic acid levels, however, were approximately three times as high in leaves of the $\mathrm{CuCu}$ genotypes as in cucu leaves. The influence
Table 1-Recovery of authentic melilotic acid chromatographed alone and in combination with coumarin and $o$-coumaric acid. Solvent was $n$-propyl alcohol, 3 vols., and $5 \% \mathrm{NH}_{4} \mathrm{OH}, 1$ vol Each figure tepresents the mean of 8 determinations.

\begin{tabular}{lcc}
\hline \multicolumn{1}{c}{ Treatment } & $\begin{array}{c}\text { Optical density, } \\
\text { mean } \pm \text { S. E. }\end{array}$ & $\begin{array}{c}\text { Recorery, } \\
\%\end{array}$ \\
\hline $\begin{array}{l}4 \gamma \text { melilotic acid alone: } \\
\text { Not chromatographed }\end{array}$ & \\
$\begin{array}{l}\text { Chromatographed alone } \\
2 \gamma \text { melilotic acid: }\end{array}$ & $\begin{array}{c}0.259 \pm 0.002 \\
0.258 \pm \mathbf{0 . 0 0 3}\end{array}$ & 99.6 \\
$\begin{array}{l}\text { Not chromatographed } \\
\text { Chromatographed with } 100 \gamma \text { cournarin } \\
\text { and } 100 \gamma \text { o-coumaric acld }\end{array}$ & $0.133 \pm 0.001$ & \\
\hline
\end{tabular}

Table 2-Melilotic acid contents of young leaves from sweetclover plants representing 4 genotypes. Fifty plants of each genotype were used in preparing the 4 extracts for assay and 5 separate assays of each extract were made.

\begin{tabular}{lcr}
\hline Genotype & \multicolumn{2}{c}{ Melilotic acid contents (\% of dry welght) mean \pm S.E. } \\
\cline { 2 - 3 } & Free & Total \\
\hline CuCuBB & $.005 \pm .0003$ & $.068 \pm .0007$ \\
CuCubb & $.005 \pm .0003$ & $.062 \pm .0003$ \\
cucuBB & $.004 \pm .0003$ & $.022 \pm .0006$ \\
cucubb & $.004 \pm .0003$ & $.021 \pm .0008$ \\
\hline
\end{tabular}

of the $\mathrm{Cu} / \mathrm{cu}$ gene pair on melilotic acid level, therefore, appears to be qualitatively similar to but quantitatively less than the effect of this gene pair on level of o-hydroxycinnamic acid (3).

\section{SUMMARY}

A modified procedure for the assay of melilotic acid in sweetclover leaves is described. The procedure provides for (a) extraction of melilotic acid and melilotyl glucoside by autoclaving the plant tissue in water, (b) hydrolysis of melilotyl glucoside by autoclaving in $1 \mathrm{~N} \mathrm{HCl}$, (c) separation of melilotic acid from interfering compounds by paper chromatography, and (d) colorimetric assay of the chromatographically-separated melilotic acid. Application of the procedure to plants representing various genotypes of sweet. clover yielded results indicating that the melilotic acid content of leaves from plants high in content of o-hydroxycinnamic acid is about three times as high as that of leaves from plants low in $o$-hydroxycinnamic acid.

\section{LITERATURE CITED}

1. Gor7, H. J., and Haskins, F. A. Genetic blocks in the synthesis of coumarin in Melilotus alba. J. Hered. 51:74-76. 1960

2. 'HASkins, F. A., and Gorz, H. J. Assay of cis- and trans-o. hydroxycinnamic acids in sweetclover extracts. Biochem. and Biophys, Res. Comm. 6:298-303. 1961.

3. _ , and A reappraisal of the rela. tionship between free and bound coumarin in Melilotus. Crop Sci. $1: 320-323$. 1961 .

4. Kosugr, T. Studies on the identity of bound coumarin in sweet clover. Arch. Biochem. Biophys. 95:21 1-218. 1961.

5. - and CoNN, E. E. The metabolism of aromatic compounds in higher plants. I. Coumarin and o-coumaric acid J. Biol. Chem. 234:2133-2137. 1959.

6. - and The metabolism of atomatic compounds in higher plants. III. The $\beta$-glucosides of $o$-coumaric, coumarinic, and melilotic acids. J. Biol. Chem 236:1617-1621. 1961 .

7. RoBleRTS, W. L., and LINK, K. P. Determination of coumarin and melilotic acid. A rapid micromethod for determination in Melilotus seed and green tissue. Ind. and Eng. Chem., Anal. Ed. 9:438-441. 1937 .

8. RudorF, W., and SCHWARze, P. Beiträge zur Züchtung eines cumarinfreien Steinklees und Untersuchungen über Cumarin und verwandte Verbindungen. Z. f. Pflanzenzücht. 39:245274. 1958.

9. Schaeffer, G. W., Haskins, F. A., and Gorz, H. J. Genetic control of coumarin biosynthesis and $\beta$-glucosidase activity in Melilotus alba. Biochem. and Biophys. Res. Comm. 3:268271. 1960

10. Smith, I. Chromatographic Techniques. William Heinemann Medical Books, Ltd. London. 1958. 